\title{
AESTHETICS OF SUSTAINABILITY: CAPSULE ARCHITECTURE IN THE CITY AND IN NATURE
}

Peter Šenk

\author{
A B S T R A C T
}

Architecture of minimum dwellings has been a hot topic recently. When minimum dwellings are compact, well-equipped, connected to the network, structurally, functionally and visually recognized as one thing, temporary and mobile or transportable, they may be designated as capsule architecture. Temporary by nature, these small dwellings, shelters, redesigned container units, special technological structures, parasites and other manifestations of the capsules concept encompass the logic of technological facilities with a distinct architectural expression. At the same time, it is a manifestation of the rule of sustainable design, sustainable architecture and sustainability in general. In this context, the case of small dwellings shows its difference as opposed to other sustainable architecture approaches and aesthetics. It subverts the generally sustainable approaches with exposed importance of locality within the global forces, usually relying on context - location, local culture and environmental characteristics, etc. The aesthetic regime of temporary, changeable, a-contextual and autonomous architectural structures can be regarded as an aesthetics of otherness, which relates them to the legacy of the Modern movement's existenzminimum experiments, the New Brutalism, radical experiments of the 1960s and other avantgarde and neo-avantgarde practices of the twentieth century, but firmly placed in the context of individualized, indeterminate, dispersed and ambiguous contemporaneity. 


\section{INTRODUCTION}

A UN News online article from July 2018 entitled "Small and sustainable: 'Tiny houses' could be a solution to world's housing problems" recapitulates the state of affairs in contemporary architectural efforts - how to provide decent and affordable housing that is as environmentally-friendly as possible. The house, 22 square meters in floorplan, was designed by UN Environment and the Centre for Ecosystems in Architecture at Yale University in the United States, in collaboration with UN-Habitat. ${ }^{1}$ Architecture of minimum dwellings, like small houses, shelters or cabins, has been a hot topic, especially after the most recent global financial crisis. While these architectures may combine Buckminster Fuller's maxim of "doing more with less," the Australian Aboriginal reinterpretation paraphrased by Glenn Murcutt as "touching the Earth lightly" or the functionalist rigor of Hannes Meyer's "function times economics," they may be extremely sophisticated architectural objects or low-tech, self-built or improvised facilities with an inbuilt minimum environmental footprint.

Although this discussion attempts to be relevant for contemporary conditions, we can find approaches and examples dealing with such environmental issues in the heroic utopian visions of future dwellings in the beginning of twentieth century that escalated with the revolutionary 1960s. Fuller's Dymaxion and other endeavors may be the most obvious examples, as well as the countercultural formations in the US, with the parallels in experimental practices in the UK, Japan and elsewhere. Most of the architectural experiments were premature, unlikely to be built even after the post-World War Two conditions, but thought about and designed in times when imagining a brighter future was an appreciated, if not an expected, endeavour.

In this paper I will argue that the legacy of visionary thinking behind the experimental architecture of the 1960 s can be a valid ground to rethink contemporary responsible, responding sustainable architecture. For this purpose, I will discuss the topics related to minimum dwellings as an extreme version of small or tiny houses, namely the sustainability conditions inherent in pioneering and contemporary capsule architecture, which has, with its inception, become the "biggest" contemporary architectural monad, the minimum building block of architecture. ${ }^{2}$ Exposing the questions of the aestehics of change, and the aesthetics of the envelope, the case of capsule architecture shows the potential for a wider social and political engagement of architecture. 


\section{MININMUM DWELLINGS: THE CAPSULES}

The extrapolation of the trend of minimising the living space, the 1929 Congrès Internationaux d'Architecture Moderne (CIAM) theme Existenzminimum can result in a capsule architecture with its own typology. But this operation is not formal only. The conditions and consequences of the trend are becoming visible within it.

When minimum dwellings are compact, well-equipped, connected to the network, structurally, functionally and visually recognised as one thing, temporary and mobile or transportable, they may be designated as capsules. ${ }^{3}$ Although there have been many more capsules designed than have actually been built or produced, they inevitably serve as a precursor and a historical reference for the contemporary derivations. While pioneering examples focused more on their spatial, social and political role, i.e. the capsules of Archigram or the Japanese Metabolists, the contemporary ones have acquired an environmental role as well. (Ecocapsule, LEAPhut, m-ch).

Capsule architectures bring a seed of otherness to the environment. ${ }^{4}$ Their mobility and uprootedness or non-attachment to a place may redefine the notion of dwelling and consequently the notion of home, an individual and community. The otherness is supported also by the physical properties that enable seclusion and autonomy. Capsules are, therefore, potentially off the grid, and may be enacted either in remote natural environments or in the urban or suburban conditions of the globalised world. These characteristics enable the concept to be appropriated in crisis areas and stimulate experiments in the fields of design and art, as well. Although seeking disconnection from the immediate environment, these architectures enable or even enhance connectedness to the non-physical information network. Temporary by their nature, these small dwellings, shelters, redesigned container units, special technological structures, parasites and other manifestations of the capsule concept encompass the logic of technological facilities with a distinct architectural expression. In capsule architecture, the temporality and change which usually falls out of the descriptions of traditional architecture, get a prominent role. This attribute defines capsule architecture through mimesis, in the sense of biomimicry, which is a widely-featured strategy for sustainable architecture, as well. ${ }^{5}$ 


\section{AESTHETICS OF CHANGE}

There is a legacy of understanding change in architecture, which was a theme proposed by Team 10 for the CIAM congress in Dubrovnik in 1956, and which was, in a more biological sense, implemented by the Japanese Metabolists in the 1960s. The term metabolism itself signifies the process of change in the span from formation to destruction and, in many cases, a new formation.

Kisho Kurokawa described his aesthetic approach as a desire for the natural, unadorned, plain, rustic and slightly sad expression depicted by notions of the "the aesthetics of Metabolism" and "the aesthetics of time". ${ }^{6}$ These may be related to those of New Brutalism, and preserve relationships between architecture, society and nature which constantly changes with time. Change in Metabolist architecture is functional and representational. It can be seen in the proposed possibility of expansions, "organic" growth, flexibility in organisation and the changeability of individual building elements, as well as larger structural entities. The aesthetic of change is well-described by Kurokawa, when observing the construction and deconstruction of his threedimensional space-frame structure with capsule units at the Osaka '70 World Fair, named Takara Beautillion. As its assembly took only a few days, its 'disassembly was similarly easy to perform; it was like the falling petals of a cherry blossom tree...,' which mirrors Buddhist aesthetics: 'In Buddhism it is considered noble to fulfill one's life and pass away beautifully, in accord with nature." 7 Constant change in Metabolist architecture is facilitated by replaceable components with various lifespans and durability, which has been part of the traditional Japanese wooden architecture, with the Ise shrine as an obvious reference. ${ }^{8}$ The ritual of building and demolition of Shintoist shrines has alternated on two enclosed sites every 20 years for centuries. The concept of perpetual change and cyclical time is installed in the concept and design of the shrine. The physical buildings are, therefore, not considered durable. In Ise: Prototype of Japanese Architecture, Noboru Kawazoe explains that the "intangible essence within the style" was actually the essence to be preserved and not the material substance of the buildings, while pointing out the significant difference between the Japanese and Western notions of art:

'The Japanese thought that life becomes eternal by being absorbed into the great stream of Nature. For them, it was not a case of "life is short, art eternal." They had only to look to the Ise Shrine-ever new, yet ever unchanging - to know that it is art, in truth, that is short and life that is eternal. ${ }^{9}$ 
While the Metabolists were exposed to the metaphorical organic feature of changing structures, their Western contemporaries emphasised the aesthetics of change. The latter were seen in the "fathers of Pop" experiments and existentialist criticism by Independent Group, as well as in ironic or intentionally frivolous proposals of Archigram. With them, architecture became predominantly a promise of an immediate future.

\section{AESTHETICS OF SUSTAINABILITY: POLITICS OF THE ENVELOPE}

Next to organic operativity of capsule architecture, which does expose a specific aesthetics of sustainability, its "total beauty" could be tested. To illustrate it and as a checklist, let's quickly relate the performance of capsule typology to Peter Buchanan's well-known "ten shades of green architecture"10: while capsule architecture can respond to demands of "low energy/high performance", "replenishable resources", "recycling", "health and happiness" and "total life cycle costing", other categories, such as "embodied energy", "long life loose fit", "embedded in place" are out of its scope. The two remaining categories, namely "access and urban context" and "community and connections" are subject to testing beyond typological determination. The quick evaluation shows that capsule architecture can respond to five categories and possibly another two (categories), while it cannot respond to three of the ten categories mentioned above in total. This evidence makes it difficult to prove that capsule architecture is sustainable in the traditional sense. Nevertheless, the three missing categories can be challenged. Since capsule architecture is not architecture in the traditional sense, its characteristic power may overshadow these missing categories in favour of other virtues, which involve the political sphere. The political performance of architecture has been historically connected to the architectural plan, which organised the power structures and protocol, and to the architectural section, which organised the social strata and the relation to the ground, while the envelope has held a mere representational or symbolic function ${ }^{11}$ with visuality (of the building) considered as "the location of its aesthetic interest". ${ }^{12}$

But due to its size and compactness, a gaze can take in the capsule at once. The envelope conveys the message reflecting the content, therefore the envelope can be regarded the display of the aesthetic, as well as political, consideration. But in the case of the capsule, the envelope is a double-sided medium and should be analysed as such. 
According to Marshall McLuhan, housing functions as extension of our skin and heat control mechanisms and a medium of communication. While it provides protection and comfort to the body, it also shapes and rearranges the patterns of human association and community. ${ }^{13}$

To be more specific, the envelope of a capsule as an external medium separates exterior from interior and can be more precisely defined by its characteristics: the structure that includes physical tightness and control mechanisms; the materiality and integrity, which makes a capsule a single-space element with either a frame or monocoque construction; and the derived representation. The form is defined by the type of the capsule and the agglomeration or siting properties. ${ }^{14}$ The envelope as an archetype of architecture mirrors a cave shelter from the distant past and can be traced as the most primordial architectural element in the tectonic theory by Gottfried Semper - the creation of the envelope by weaving. With contemporary technology, the envelope is completed with perfected physical control mechanisms, which do not only protect the user against external influences. Highly functioning building envelopes are crucial for the edifice's sustainable performance, as well. ${ }^{15}$ But in many cases in contemporary architecture, the envelope becomes the sole technological response in architectural disguise. Such a position promotes 'science and technology as the solutions that will repair ecological damage without interfering with consumerist lifestyles or worldviews'. ${ }^{16}$

The specific architectural quality of the capsule is, in this case, emphasised by the double-sidedness of the envelope and its multiplied activity. What capsule architecture performs as architecture is distinct from just the parameters of sustainability. Namely, the characteristic of the capsule architecture refers to the internal part of its envelope, which enables comfort within. By means of an interface, the comfort is provided by the ergonomic character of furnishings, equipment facilitating the regulation of the influence flow from the outside, the transfer between inside and outside, and adjustments for the desired ambiance inside. It also enables a potential functional autonomy of the capsule. ${ }^{17}$

To quote Zaera-Polo from The Politics of the Envelope, 'at a time when energy and security concerns have replaced an earlier focus on circulation and flow as the contents of architectural expression, the building envelope becomes a key political subject', which is reflected, for example, in Sloterdijk's Sphären trilogy. 
With its treatment of the envelope as a "double-sided surface", it enables it to go beyond superficial interactivity or environmental effectiveness and actually can provide the conditions of mediation between the interior and exterior, as well as their embodiment. With this understanding, the envelope is not solely an addition, passive or superficial, since the surface design is blended with the essence of architecture. ${ }^{19}$ To paraphrase Zaera-Polo, it has become 'an image of engagement between the individual and the collective, and therefore a mechanism of political expression of contemporary societies'. ${ }^{20}$ According to the three models of building envelopes proposed by Lee and Holzheu: ${ }^{21}$ from the modernist "form follows function" through the Venturian "form accommodates function" to the biomimetic generative system responsive and adaptable to environmental or parametric conditions, i.e. "form is function," which the authors position within the politics of biomimetics, the pioneering capsule architecture has been a product of the late modernist period, but we can understand its operation in a rather contemporary - biomimetic way. The latter is also especially clear with the contemporary derivations of the concept.

\section{CONCLUSION}

The exposed aesthetics of change, and the aesthetics of the envelope show the potential of architecture for a wider social and political engagement.

Capsule architecture is, at the same time, a manifestation of the rule of sustainable design, sustainable architecture and sustainability in general, but shows its difference to other sustainable architecture approaches and aesthetics. It subverts some of the generally-sustainable approaches. The aesthetic regime of temporary, changeable, acontextual and autonomous architectural objects can be regarded as an aesthetics of otherness that carries political connotations. These relate capsule architecture to the legacy of the Modern movement's existenzminimum experiments, the New Brutalism, radical experiments of the 1960s and other avantgarde and neo-avantgarde practices of the twentieth century, but firmly placed within the context of individualised, indeterminate, dispersed and ambiguous contemporaneity. 
Due to their otherness, distinct from traditional dwellings, they demand attention and elicit reactions. The idea behind the concept is, of course, a rather libertarian one, which may lead to chaotic situations in space and even anti-bureaucracy, as it was already exposed by the Metabolists back in the 1960s. For discussion of otherness of the typology of the capsule, see Šenk, Capsules.

Sang Lee and Stefanie Holzheu, "Building Envelope as Surface," in Aesthetics of Sustainable Architecture, ed. Sang Lee (Rotterdan, 010 Publishers, 2011); Richard Ingersoll, "The Ecology Question and Architecture," in The Sage Handbook of Architectural Theory, ed. C. Greig Crysler, Stephen Cairns and Hilde Heynen (London, etc.: Sage Publications, 2013), 585-6. 
Kenzo Tange and Noboru Kawazoe, Ise: Prototype of Japanese Architecture (Cambridge, MA: MIT Press, 1965), 202, 206.

Peter Buchanan, Ten Shades of Green: Architecture and the Natural World (New York: The Architectural League of New York, 2005).

Alejandro Zaera-Polo, “The Politics of The Envelope,” Log, no. 13/14 (Fall 2008): 185.

Marshall McLuhan, Understanding Media: The Extensions of Man (Corte Madera: Gingko Press, 2003), 173. First published 1964. McLuhan treats clothing and housing together in this category.

Lee and Holzheu, "Building Envelope as Surface," 122.

Ingersoll, "The Ecology Question and Architecture," 582.

Šenk, Capsules, 154-156.

Zaera-Polo, "The Politics of The Envelope," 197.

Zaera-Polo, "The Politics of The Envelope," 202. 
Buchanan, Peter. Ten Shades of Green: Architecture and the Natural World. New York: The Architectural League of New York, 2005.

Ingersoll, Richard. "The Ecology Question and Architecture." In: The Sage Handbook of Architectural Theory, ed. C. Greig Crysler, Stephen Cairns and Hilde Heynen. London, etc.: Sage Publications, 2013.

Kikutake, Kiyonori and Vitta, Maurizio. Kiyonori Kikutake: From Tradition to Utopia. Milano: l'Arca Edizioni, 1997.

Kurokawa, Kisho. Metabolism in Architecture. London: Studio Vista, 1977.

Lee, Sang and Holzheu, Stefanie. "Building Envelope as Surface.” In: Aesthetics of Sustainable Architecture, ed. Sang Lee. Rotterdan, 010 Publishers, 2011.

McLuhan, Marshall. Understanding Media: The Extensions of Man. Corte Madera: Gingko Press, 2003. (First published 1964.)

"Small and sustainable: 'Tiny houses' could be solution to world's housing problems," UN News 17 July 2018, accessed February 17, 2019. https://news.un.org/en/story/2018/07/1014982.

Šenk, Peter. Capsules: Typology of Other Architecture. London, New York: Routledge, 2018.

Tange, Kenzo and Kawazoe, Noboru. Ise: Prototype of Japanese Architecture. Cambridge, MA: MIT Press, 1965

Winters, Edward. Aesthetics \& Architecture. London, New York: Continuum, 2007.

Zaera-Polo, Alejandro. “The Politics of The Envelope.” Log, no. 13/14. Fall 2008. 


\section{ESTETIKA ODRŽIVOSTI: ARHITEKTURA KAPSULE U GRADU I U PRIRODI Peter Šenk}

Arhitektura najmanjih mesta za stanovanje je u poslednje vreme izuzetno popularna tema. Kada su najmanja mesta za stanovanje kompaktna, dobro opremljena, povezana na mrežu, strukturno, funkcionalno i vizuelno prepoznata kao jedna stvar, privremena i pokretna ili prenosiva, mogu se označiti kao arhitektura kapsule. Budući da su po svojoj prirodi privremena, ova najmanja mesta za stanovanje, skloništa, redizajnirane kontejnerske jedinice, posebne tehnološke konstrukcije, paraziti i druge manifestacije koncepta kapsula obuhvataju logiku tehnoloških objekata s izrazitim arhitektonskim izrazom. To je, istovremeno, manifestacija pravila održivog dizajna, održive arhitekture i održivosti uopšte. U ovom kontekstu slučaj najmanjih mesta za stanovanje pokazuje svoju razliku u odnosu na druge održive arhitektonske pristupe i estetike. Podredjuje uopšteno održive pristupe sa izraženim značajem lokaliteta unutar globalnih sila, obično se oslanjajući na kontekst - lokaciju, lokalnu kulturu i karakteristike životne sredine itd. Estetski režim trenutnih, promenljivih, kontekstualnih i autonomnih arhitektonskih struktura se može posmatrati kao estetika drugosti, koja ih povezuje sa nasledjem egzistencijalnih eksperimenata modernog pokreta, novim brutalizmom, radikalnim eksperimentima 1960-ih i drugim avangardnim i neoavangardnim praksama dvadesetog veka, ali čvrsto postavljenim u kontekstu individualizovane, neodredjene, raspršene i dvosmislene savremenosti.

KLJUČNE REČI: ESTETIKA PROMENE, KAPSULE, NAJMANJA MESTA ZA STANOVANJE, MINIMALAN TRAG, DRUGOST, ESTETIKA ODRŽIVOSTI

\section{ESTETIKA I KULTUROLOŠKI ASPEKTI BAUHAUSA: \\ KA NOVOJ KONCEPCIJI}

\section{Christiane Wagner}

Ovaj članak pokriva nove mogućnosti Bauhaus pogleda na svet: stvaranje novih oblika za prikazivanje ljudskih ideala kroz fokus na estetiku i tehnologiju, u kombinaciji sa Nimajerovim (Niemeyer) uticajem na arhitekturu i dizajn. Novi stilovi i oblici nastali su kao izdanci Bauhausa, prenoseći vrednosti svake kulture kroz izgradnju kolektivne „slike“ sveta. Bauhaus današnjice izražava industriju kulture, dijalektički razmatrajući inovaciju i primenjenu umetnost kao put od modernog dizajna industrijske revolucije do „eko dizajna“. U tom smislu, Bauhaus je još uvek značajan po svojoj ulozi, povezujući umetnost, tehnologiju i industriju. Inovacija kao dinamično odredjivanje trenutka, prisutna u svim epohama, se shvata kao moćna sila za održavanje tradicije. Pored hronološkog zapisa o uticaju Bauhausa, razmatraju se i značajni Nimajerovi projekti. Na kraju su prikazane dve perspektive ,raskola“ izmedju arhitekture i tehnologije. Prva perspektiva se odnosi na ljudsku sposobnost stvaranja modela u arhitektonskoj praksi za usvajanje kao konfiguraciju prostora. Druga se odnosi na evoluciju tehnologija koje vode do toga da zamišljeno postaje stvarnost kroz vreme, kako je to opisao Hegel (1823).

KLJUČNE REČI: IZRADA PO MERI, TEHNOLOŠKI RAZVOJ, PROSTOR-VREME, NOVI OBLICI

\section{KLASIČNA ARHITEKTURA U OKVIRU KANTOVSKE ESTETIKE: IZMEĐU LIOTARA I RANSIJERA}

\section{Helen Tatla}

Potencijal koji je svojstven klasičnoj arhitekturi da predstavlja glavni arhitektonski izraz zapadne kulture budući da je grčka antika nastala zbog svog dualnog karaktera: iako izvire iz iskonskog jedinstva stvari izraženih mitom i religijom u arhaičnim vremenima, ona dobija svoj završni oblik u petom veku p. n. e., kao simbol demokratije i harmonične artikulacije sveta na osnovu filozofskog mišljenja. 